\title{
Liharotuisten sonnien ja hiehojen kasvu- ja teurasominaisuudet
}

\author{
Arto Huuskonen ${ }^{1)}$, Maiju Pesonen ${ }^{1)}$ ja Maarit Hyrkäs ${ }^{2)}$ \\ ${ }^{1)}$ Maa- ja elintarviketalouden tutkimuskeskus, Kotieläintuotannon tutkimus, Tutkimusasemantie 15, \\ 92400 Ruukki,arto.huuskonen@mtt.fi, maiju.pesonen@mtt.fi \\ ${ }^{2)}$ Maa- ja elintarviketalouden tutkimuskeskus, Kotieläintuotannon tutkimus, Halolantie 31A, 71750 \\ Maaninka, maarit.hyrkas@mtt.fi
}

\section{Tiivistelmä}

Tutkimuksella haluttiin selvittää liharotuisten nautojen kasvu- ja teurasominaisuuksia. Tutkimusaineistona oli teurastamoilta saatu naudan ruhojen teurasaineisto, johon yhdistettiin ProAgria Maatalouden Laskentakeskuksen kautta saadut rotutiedot. Teurastamoaineistoa oli käytössä HK Agri Oy:ltä ja Snellman Lihanjalostus Oy:ltä vuodesta 2007 lähtien, A-Tuottajat Oy:Itä vuodesta 2008 lähtien ja Saarioinen Lihanjalostus Oy:Itä vuodesta 2010 lähtien. Hiehojen osalta alle 300 ja yli 550 vrk:n ikäiset eläimet jätettiin datasta pois. Vastaavasti sonnien osalta alle 365 ja yli 660 vrk:n ikäiset eläimet jätettiin datasta pois. Tutkimuksessa vertailtavia rotuja olivat aberdeen angus (ab), hereford (hf), limousin (li), charolais (ch), simmental (si) ja blonde d'Aquitaine (ba). Eläimen katsottiin edustavan kyseistä rotua, jos sen molemmat vanhemmat olivat ProAgria Maatalouden Laskentakeskuksen aineistossa luokiteltu ao. rodun edustajiksi. Näiden rajausten jälkeen tutkimusaineisto sisälsi 21643 teurastettua liharotuista sonnia ja 8743 liharotuista teurashiehoa. Roduittain ja sukupuolittain lopullinen aineisto muodostui seuraavasti: ab 4068 sonnia, 1692 hiehoa; hf 6323 sonnia, 2385 hiehoa; li 4335 sonnia, 1951 hiehoa; ch 4421 sonnia, 1794 hiehoa; si 2152 sonnia, 774 hiehoa; ba 344 sonnia, 147 hiehoa.

Sonnien kasvatusaika (vrk) ja teuraspaino $(\mathrm{kg})$ muodostuivat roduittain seuraaviksi: ab (571 vrk, $368 \mathrm{~kg}$ ), hf (572 vrk, $368 \mathrm{~kg})$, li (571 vrk, $391 \mathrm{~kg})$, ch (552 vrk, $413 \mathrm{~kg})$, si (565 vrk, $402 \mathrm{~kg})$ ja ba (570 vrk, $393 \mathrm{~kg}$ ). Teuraspainojen osalta ainoastaan ab- ja hf-rodun sonnit sekä li- ja ba-sonnit eivät eronneet keskenään tilastollisesti merkitsevästi toisistaan. Kaikkien muiden rotujen välillä ero teuraspainossa oli merkitsevä $(\mathrm{p}<0.001)$. Sonnien nettokasvu $(\mathrm{g} / \mathrm{pv})$, lihakkuusluokka (EUROP) ja rasvaisuusluokka (EUROP) olivat roduittain seuraavat: ab (619 g/pv, R-, 3,3), hf (618 g/pv, R-, 3,2), li (660 $\mathrm{g} / \mathrm{pv}, \mathrm{U}-, 2,2)$, ch (724 g/pv, R+, 2,2), si (686 g/pv, R, 2,3) ja ba (663 g/pv, U-, 1,8). Nettokasvuissa ab ja hf-rodun sonnit sekä li- ja ba-sonnit eivät eronneet keskenään tilastollisesti merkitsevästi toisistaan, mutta kaikkien muiden rotujen välillä ero oli merkitsevä $(\mathrm{p}<0.001)$. Ruhojen lihakkuudessa ei ollut tilastollista merkitsevyyttä ab- ja hf-rotujen välillä; kaikki muut erot olivat tilastollisesti merkitseviä. Ruhojen rasvaisuudessa kaikki rodut erosivat toisistaan tilastollisesti merkitsevästi.

Hiehojen keskimääräinen kasvatusaika oli 462 vrk. Teuraspaino (kg), nettokasvu (g/pv), lihakkuusluokka (EUROP) ja rasvaisuusluokka (EUROP) olivat roduittain seuraavat: ab $(233 \mathrm{~kg}, 478 \mathrm{~g} / \mathrm{pv}$, $\mathrm{O}, 3,9)$, hf (252 kg, $468 \mathrm{~g} / \mathrm{pv}, \mathrm{O}, 3,9)$, li (250 kg, $504 \mathrm{~g} / \mathrm{pv}, \mathrm{R}-, 2,9)$, ch (255 kg, $538 \mathrm{~g} / \mathrm{pv}, \mathrm{R}-, 2,9)$, si $(244 \mathrm{~kg}, 510 \mathrm{~g} / \mathrm{pv}, \mathrm{O}+, 3,0) \mathrm{ja}$ ba $(252 \mathrm{~kg}, 500 \mathrm{~g} / \mathrm{pv}, \mathrm{R}, 2,3)$. Teuraspainojen osalta ab- ja hf-rodun hiehot, ba- ja ch-hiehot sekä li- ja ba-hiehot eivät eronneet keskenään tilastollisesti merkitsevästi toisistaan, mutta muiden rotujen välillä ero teuraspainossa oli merkitsevä $(\mathrm{p}<0.001)$. Nettokasvuerot ba-, li- ja si-rotuisten hiehojen välillä eivät olleet merkitseviä; kaikki muut nettokasvuerot olivat tilastollisesti merkitseviä $(\mathrm{p}<0.001)$. Ruhojen lihakkuudessa kaikki rodut erosivat toisistaan tilastollisesti merkitsevästi $(\mathrm{p}<0.001)$. Ruhojen rasvaisuudessa ei ollut tilastollista merkitsevyyttä ab- ja hf-rotujen eikä ch- ja li-rotujen välillä; kaikki muut erot olivat tilastollisesti merkitseviä $(\mathrm{p}<0.001)$.

Asiasanat: naudanlihantuotanto, liharodut, ruhon laatu, kasvu, ruhon lihakkuus, ruhon rasvaisuus 


\section{Johdanto}

Kotimaista tutkimustietoa pihvirotuisten nautojen kasvu- ja teurasominaisuuksista on saatavilla rajoitetusti. Suomessa nautojen nurmisäilörehuvaltainen ruokinta poikkeaa ulkomailla käytetyistä rehustusmalleista, minkä vuoksi muualla toteutetut tutkimukset eivät ole suoraan meille sovellettavissa. Aikaisemmissa kotimaisissa pihvirotuisilla naudoilla tehdyissä tutkimuksissa on käsitelty ruokinnan (Manninen ym. 2004a,b, 2006a,b,c, 2010, 2011) ja kasvatusympäristön (Huuskonen ym. 2009, 2010) vaikutusta eläinten kasvuun ja ruhon laatuun, mutta eri rotujen välisiä vertailuja on tehty lähinnä maito-liha-risteytyseläimillä (Manninen ym. 1994). Tässä raportoitavalla tutkimuksella haluttiin selvittää liharotuisten nautojen kasvu- ja teurasominaisuuksia laajan data-aineiston pohjalta. Tutkimus oli osa MTT Ruukin toimipisteen hallinnoimaa InnoNauta Kehitys -hanketta.

\section{Aineisto ja menetelmät}

Tutkimusaineistona oli teurastamoilta saatu naudan ruhojen teurasaineisto, johon yhdistettiin ProAgria Maatalouden Laskentakeskuksen kautta saadut rotutiedot. Teurastamoaineistoa oli käytössä HK Agri Oy:Itä ja Snellman Lihanjalostus Oy:Itä vuodesta 2007 lähtien, A-Tuottajat Oy:ltä vuodesta 2008 lähtien ja Saarioinen Lihanjalostus Oy:Itä vuodesta 2010 lähtien. Yhdistetyssä datassa olivat mukana seuraavat tiedot: eläimen syntymätunnus, teurastuspäivä, teuraspaino, teurastuksessa hylättyjen osien paino, ruhon laatuluokka, ruhon rasvaisuusluokka, eläimen syntymäaika, eläimen sukupuoli, eläimen rotukoodi, eläimen emän rotukoodi ja eläimen isän rotukoodi. Teurasruhot oli teurastamoissa punnittu ja luokiteltu EUROP - luokituksen mukaisesti. Nettokasvutulosten laskemiseksi dataan lisättiin uutena muuttujana eläimen lihapaino syntyessä (alkupaino). Tämä lisättiin oletusarvona siten, että alkupainoksi määritettiin sonnivasikalle $16 \mathrm{~kg}$ ja lehmävasikalle $15,2 \mathrm{~kg}$. Vastaavia arvioita A-Tuottajat Oy käyttää päivittäisessä työssään (Herva ym. 2009). Nettokasvu laskettiin teuraspainon ja kokeen alun lihapainon erotuksena jaettuna kasvatuspäivillä.

Tutkimuksessa vertailtavia rotuja olivat aberdeen angus (ab), hereford (hf), limousin (li), charolais (ch), simmental (si) ja blonde d'Aquitaine (ba). Eläimen katsottiin edustavan kyseistä rotua, jos sen molemmat vanhemmat olivat ProAgria Maatalouden Laskentakeskuksen aineistossa luokiteltu ao. rodun edustajiksi. Hiehojen osalta alle 300 ja yli 550 vrk:n ikäiset eläimet jätettiin datasta pois. Vastaavasti sonnien osalta alle 365 ja yli 660 vrk:n ikäiset eläimet jätettiin datasta pois. Näiden rajausten jälkeen tutkimusaineisto sisälsi 21643 teurastettua liharotuista sonnia ja 8743 liharotuista teurashiehoa. Roduittain ja sukupuolittain lopullinen aineisto muodostui seuraavasti: ab 4068 sonnia, 1 692 hiehoa; hf 6323 sonnia, 2385 hiehoa; li 4335 sonnia, 1951 hiehoa; ch 4421 sonnia, 1794 hiehoa; si 2152 sonnia, 774 hiehoa; ba 344 sonnia, 147 hiehoa.

Tilastollisena käsittelynä tuloksille tehtiin varianssianalyysi SAS 9.2. -ohjelmiston MIXEDproseduurilla. Rotujen välisten erojen tilastollinen merkitsevyys testattiin Tukeyn-Kramerin -testillä.

\section{Tulokset ja tulosten tarkastelu Kasvatusaika, kasvu-ja teurastulokset}

Sonnien kasvu- ja teurastulokset käyvät ilmi taulukosta 1. Keskimääräinen kasvatusaika oli ab-, hf-, lija ba-rodun sonneilla samanpituinen (570-572 vrk). Lyhin kasvatusaika oli ch-rodun sonneilla (552 vrk). Si-sonnien kasvatusaika oli keskimäärin 565 vrk.

Rotujen välillä oli selkeitä eroja teuraspainojen suhteen, sillä ab ja hf-rodun sonnit teurastettiin muita rotuja selvästi alemmassa teuraspainossa (keskimäärin $368 \mathrm{~kg}$ ). Li- ja ba-sonnit teurastettiin keskimäärin hieman alle $400 \mathrm{~kg}: \mathrm{n}$ painossa ja si-sonneilla teuraspaino oli $402 \mathrm{~kg}$. Kaikkein suurimpiin painoihin kasvatettiin ch-sonnit $(413 \mathrm{~kg})$.

Parhaat nettokasvutulokset saavutettiin ch-sonneilla (keskimäärin 724 g/pv). Si-, ba- ja lisonneilla keskimääräiset kasvutulokset olivat välillä 660-686 g/pv. Ab- ja hf-sonneilla kasvut olivat $620 \mathrm{~g} / \mathrm{pv}$ tasolla.

Lihakkuudeltaan parhaita olivat ba- ja li-rotujen sonnit, jotka luokittuivat keskimäärin lihakkuusluokkaan U-. Ch-sonnien lihakkuusluokka oli keskimäärin R+ ja si-sonnien R. Ab- ja hf-sonnit luokittuivat luokkaan R-.

Myös ruhojen rasvaisuudessa erot rotujen välillä olivat selkeät. Vähärasvaisimpia olivat basonnien ruhot (keskimääräinen rasvaisuusluokka 1,8). Li-, ch- ja si-sonnien rasvaisuusluokka oli hieman yli 2, kun taas ab- ja hf-sonnien ruhot luokiteltiin hieman yli 3-luokan rasvaisiksi. 
Taulukko 1. Liharotuisten sonnien kasvu- ja teurastulokset roduittain $(\mathrm{AB}=$ aberdeen angus, $\mathrm{BA}=$ blonde d'Aquitaine, $\mathrm{CH}=$ charolais, $\mathrm{HF}=$ hereford, $\mathrm{LI}=$ limousin, $\mathrm{SI}=$ simmental).

\begin{tabular}{lllllllll} 
& AB & BA & CH & HF & LI & SI & SEM $^{1}$ & $\begin{array}{c}\text { Tilastollinen } \\
\text { merkitsevyys }\end{array}$ \\
\hline Eläinmäärä, kpl & 4068 & 344 & 4421 & 6323 & 4335 & 2152 & & \\
Kasvatusaika, vrk & $571^{\mathrm{a}}$ & $570^{\mathrm{ac}}$ & $552^{\mathrm{b}}$ & $572^{\mathrm{a}}$ & $571^{\mathrm{a}}$ & $565^{\mathrm{c}}$ & 3,1 & $* * *$ \\
Nettokasvu, g/pv & $619^{\mathrm{a}}$ & $663^{\mathrm{b}}$ & $724^{\mathrm{c}}$ & $618^{\mathrm{a}}$ & $660^{\mathrm{b}}$ & $686^{\mathrm{d}}$ & 5,7 & $* * *$ \\
Teuraspaino, kg $^{\mathrm{a}}$ & $368^{\mathrm{a}}$ & $393^{\mathrm{b}}$ & $413^{\mathrm{c}}$ & $368^{\mathrm{a}}$ & $391^{\mathrm{b}}$ & $402^{\mathrm{d}}$ & 3,2 & $* * *$ \\
Lihakkuus, EUROP $^{3}$ & $6,9^{\mathrm{a}}$ & $10,3^{\mathrm{b}}$ & $9,3^{\mathrm{c}}$ & $6,9^{\mathrm{a}}$ & $9,7^{\mathrm{d}}$ & $8,2^{\mathrm{e}}$ & 0,10 & $* * *$ \\
Rasvaisuus, EUROP $^{4}$ & $3,3^{\mathrm{a}}$ & $1,8^{\mathrm{b}}$ & $2,2^{\mathrm{c}}$ & $3,2^{\mathrm{d}}$ & $2,2^{\mathrm{e}}$ & $2,3^{\mathrm{f}}$ & 0,04 & $* * *$ \\
\hline
\end{tabular}

${ }^{1}$ SEM = Keskiarvon keskivirhe.

${ }^{2}$ Tilastollisesti merkitsevästi $(\mathrm{p}<0,05)$ toisistaan eroavat keskiarvot on merkitty taulukkoon eri yläindekseillä. $* * *(\mathrm{p}<0,001), * *(\mathrm{p}<0,01), *(\mathrm{p}<0,05)$ ja o $(\mathrm{p}<0,10)$.

${ }^{3}$ Lihakkuus: $(1=$ heikoin, $15=$ paras). $1=\mathrm{P}-, 2=\mathrm{P}, 3=\mathrm{P}+, 4=\mathrm{O}-, 5=\mathrm{O}, 6=\mathrm{O}+, 7=\mathrm{R}-, 8=\mathrm{R}, 9=\mathrm{R}+, 10=\mathrm{U}-, 11=\mathrm{U}$, $12=\mathrm{U}+, 13=\mathrm{E}-, 14=\mathrm{E}, 15=\mathrm{E}+$.

${ }^{4}$ Rasvaisuus: $(1=$ rasvaton, 5 = erittäin rasvainen $)$.

Taulukko 2. Liharotuisten hiehojen kasvu- ja teurastulokset roduittain $(\mathrm{AB}=$ aberdeen angus, $\mathrm{BA}=\mathrm{blonde}$ d'Aquitaine, $\mathrm{CH}=$ charolais, $\mathrm{HF}=$ hereford, $\mathrm{LI}=$ limousin, $\mathrm{SI}=$ simmental $)$.

\begin{tabular}{lllllllll} 
& AB & BA & CH & HF & LI & SI & SEM ${ }^{1}$ & $\begin{array}{l}\text { Tilastollinen } \\
\text { merkitsevyys }\end{array}$ \\
\hline Eläinmäärä, kpl & 1692 & 147 & 1794 & 2385 & 1951 & 774 & & \\
Kasvatusaika, vrk & $458^{\mathrm{a}}$ & $475^{\mathrm{b}}$ & $451^{\mathrm{c}}$ & $465^{\mathrm{d}}$ & $469^{\mathrm{b}}$ & $453^{\mathrm{c}}$ & 4,4 & $* * *$ \\
Nettokasvu, g/pv & $478^{\mathrm{a}}$ & $500^{\mathrm{b}}$ & $538^{\mathrm{c}}$ & $468^{\mathrm{d}}$ & $504^{\mathrm{b}}$ & $510^{\mathrm{b}}$ & 6,8 & $* * *$ \\
Teuraspaino, kg $^{3}$ & $233^{\mathrm{a}}$ & $252^{\mathrm{bc}}$ & $255^{\mathrm{b}}$ & $232^{\mathrm{a}}$ & $250^{\mathrm{c}}$ & $244^{\mathrm{d}}$ & 3,1 & $* * *$ \\
Lihakkuus, EUROP $^{3}$ & $5,3^{\mathrm{a}}$ & $7,7^{\mathrm{b}}$ & $6,5^{\mathrm{c}}$ & $5,1^{\mathrm{d}}$ & $7,2^{\mathrm{e}}$ & $5,7^{\mathrm{f}}$ & 6,3 & $* * *$ \\
Rasvaisuus, EUROP $^{4}$ & $3,9^{\mathrm{a}}$ & $2,3^{\mathrm{b}}$ & $2,9^{\mathrm{c}}$ & $3,9^{\mathrm{a}}$ & $2,9^{\mathrm{c}}$ & $3,0^{\mathrm{d}}$ & 0,07 & $* * *$ \\
\hline
\end{tabular}

${ }^{1} \mathrm{SEM}=$ Keskiarvon keskivirhe.

${ }^{2}$ Tilastollisesti merkitsevästi $(\mathrm{p}<0,05)$ toisistaan eroavat keskiarvot on merkitty taulukkoon eri yläindekseillä. $* * *(\mathrm{p}<0,001), * *(\mathrm{p}<0,01), *(\mathrm{p}<0,05)$ ja o $(\mathrm{p}<0,10)$.

${ }^{3}$ Lihakkuus: $(1=$ heikoin, $15=$ paras). $1=\mathrm{P}-, 2=\mathrm{P}, 3=\mathrm{P}+, 4=\mathrm{O}-, 5=\mathrm{O}, 6=\mathrm{O}+, 7=\mathrm{R}-, 8=\mathrm{R}, 9=\mathrm{R}+, 10=\mathrm{U}-, 11=\mathrm{U}$, $12=\mathrm{U}+, 13=\mathrm{E}-, 14=\mathrm{E}, 15=\mathrm{E}+$.

${ }^{4}$ Rasvaisuus: $(1=$ rasvaton, 5 = erittäin rasvainen $)$.

Hiehojen osalta rotujen väliset erot teurasaineistojen tuloksissa olivat hyvin samansuuntaisia kuin sonneilla. Luonnollisesti kasvutasot ja teuraspainot sekä lihakkuusluokat olivat sonneja matalammat. Hiehojen tulokset käyvät ilmi taulukosta 2. Keskimääräinen kasvatusaika oli 462 vrk. Ab- ja hf-rodun hiehot teurastettiin muita rotuja matalammassa teuraspainossa (keskimäärin 232-233 kg). Korkeimmat teuraspainot saavutettiin ch- $(255 \mathrm{~kg})$ ja ba-rodun $(252 \mathrm{~kg})$ hiehoilla.

Korkeimmat nettokasvutulokset saavutettiin ch-hiehoilla (keskimäärin 538 g/pv). Si-, ba- ja lihiehojen kasvutulokset olivat välillä 500-510 g/pv. Ab- ja hf-hiehojen keskimääräinen kasvu oli selvästi alle $500 \mathrm{~g} / \mathrm{pv}$.

Lihakkuudeltaan parhaita olivat ba-hiehot luokittuen keskimäärin luokkaan R. Li- ja ch-rodun hiehojen lihakkuusluokka oli keskimäärin R-. Si-hiehot luokittuivat luokkaan O+ ja ab sekä hf-hiehot luokkaan O. Rasvaisimpia olivat ab- ja hf-hiehot, joilla rasvaisuusluokka oli keskimäärin 3,9. Li-, chja si-hiehojen rasvaisuusluokka oli keskimäärin 3. Selvästi vähiten rasvoittuivat ba-hiehot, joiden rasvaisuusluokka oli keskimäärin 2,3.

\section{Teuraspainon vaikutus ruhon rasvaisuuteen}

Suomalaisen naudanlihantuotannon määrä on pystytty säilyttämään kohtuullisesti kotimaista kysyntää vastaavana teuraspainojen nostamisen ja emolehmätuotannon lisäämisen avulla. Teuraspainojen nousu on kuitenkin samalla lisännyt jonkin verran ruhojen rasvoittumista. Naudan kasvussa tapahtuu fysiologisia muutoksia sukukypsyyden saavuttamisen jälkeen. Tämän jälkeen rasvakudoksen määrä kasvaa 
lihaksia nopeammin. Teuraspaino pitäisi pystyä valitsemaan siten, että eläin olisi kasvunvaiheessa, jossa rasvaisuus on optimitasolla. Käytännössä on kuitenkin erittäin vaikeaa määrittää tätä pistettä.

Tutkimus- ja teurasaineistoissa teuraspainon kasvu on lisännyt selkeästi ruhojen rasvaisuutta ja vähentänyt lihan ja luun osuutta ruhossa (Owens ym. 1993, Steen \& Kilpatrick 1995, Herva ym. 2011). Steenin ja Kilpatrickin (1995) mukaan teuraspainojen madaltaminen olisikin todennäköisesti tehokkain keino rajoittaa ruhojen rasvoittumista. Nykytilanteessa, jossa kotimaisen naudanlihan tarjonta ei kata kysyntää, keskiteuraspainojen madaltamiselle ei kuitenkaan liene Suomessa perusteita. Sen sijaan rotujen välillä voidaan tehdä valintaa sen suhteen, missä vaiheessa eläimet teurastetaan.

Teuraspainon vaikutus ruhojen rasvoittumiseen tuli selkeästi esille myös tässä raportoitavassa teurasaineistossa. Taulukossa 3 on esitetty roduittain sonnien keskimääräiset teuraspainot jokaisessa viidessä rasvaisuusluokassa. Jos tavoitteena pidetään sitä, että liharotuinen sonni luokittuu korkeintaan rasvaisuusluokkaan 3, tulisi ab- ja hf-rotujen eläimet teurastaa selkeästi muita rotuja alhaisimmissa teuraspainoissa. Ab-sonnien osalta rasvaisuusluokkaan 3 luokittuva eläin painoi tässä aineistossa keskimäärin $366 \mathrm{~kg}$. Vastaava teuraspaino oli hf-sonneilla $369 \mathrm{~kg}$. Muiden rotujen osalta rasvaisuusluokan 3 sonnit pystyttiin kasvattamaan selkeästi yli $400 \mathrm{~kg}: n$ teuraspanoihin. Blonde d'Aquitainen osalta on huomattava, että aineiston koko ei anna selkeää kuvaa rodun rasvoittumistaipumuksesta. Nyt rasvaisuusluokkaan 4 luokittui ainoastaan 9 ba-rodun eläintä, joiden keskimääräinen teuraspaino oli matalampi kuin rasvaisuusluokan 3 sonneilla. Onkin todennäköistä, että nämä 9 sonnia eivät edusta kovinkaan hyvin ba-rodun keskimääräistä eläinainesta.

Taulukko 3. Liharotuisten sonnien keskimääräinen teuraspaino eri rasvaisuusluokissa ( $\mathrm{AB}=$ aberdeen angus, $\mathrm{BA}$ = blonde d'Aquitaine, $\mathrm{CH}=$ charolais, $\mathrm{HF}=$ hereford, $\mathrm{LI}=$ limousin, $\mathrm{SI}=$ simmental).

\begin{tabular}{llllllllll}
$\begin{array}{l}\text { Rasvaisuus- } \\
\text { luokka }\end{array}$ & $\begin{array}{l}\text { Havaintojen } \\
\text { lukumäärä }\end{array}$ & AB & BA & CH & HF & LI & SI & SEM $^{1}$ & $\begin{array}{l}\text { Tilastollinen } \\
\text { merkitsevyys }\end{array}$ \\
\hline 1 & 1660 & $244^{\mathrm{a}}$ & $371^{\mathrm{b}}$ & $362^{\mathrm{bc}}$ & $224^{\mathrm{d}}$ & $342^{\mathrm{e}}$ & $351^{\mathrm{ce}}$ & 7,4 & $* * *$ \\
2 & 8172 & $331^{\mathrm{a}}$ & $406^{\mathrm{b}}$ & $409^{\mathrm{b}}$ & $326^{\mathrm{a}}$ & $391^{\mathrm{c}}$ & $395^{\mathrm{c}}$ & 4,4 & $* * *$ \\
3 & 7180 & $366^{\mathrm{a}}$ & $412^{\mathrm{b}}$ & $435^{\mathrm{c}}$ & $369^{\mathrm{a}}$ & $412^{\mathrm{d}}$ & $424^{\mathrm{b}}$ & 8,8 & $* * *$ \\
4 & 3776 & $388^{\mathrm{a}}$ & $400^{\mathrm{a}}$ & $456^{\mathrm{b}}$ & $391^{\mathrm{a}}$ & $434^{\mathrm{c}}$ & $447^{\mathrm{b}}$ & 16,5 & $* * *$ \\
5 & 855 & $406^{\mathrm{a}}$ & & $446^{\mathrm{b}}$ & $410^{\mathrm{a}}$ & $422^{\mathrm{ab}}$ & $452^{\mathrm{b}}$ & 19,8 & $* *$ \\
\hline
\end{tabular}

${ }^{1}$ SEM = Keskiarvon keskivirhe

${ }^{2}$ Tilastollisesti merkitsevästi $(\mathrm{p}<0,05)$ toisistaan eroavat keskiarvot on merkitty taulukkoon eri yläindekseillä. $* * *(\mathrm{p}<0,001), * *(\mathrm{p}<0,01), *(\mathrm{p}<0,05)$ ja o $(\mathrm{p}<0,10)$.

Myös hiehojen osalta ruhon rasvoittumisen ja teuraspainon välinen yhteys tuli aineistossa selkeästi esille (Taulukko 4). Rotujen väliset erot rasvoittumistaipumuksessa olivat hyvin samansuuntaisia kuin sonneilla. Ab- ja hf-rodun hiehoilla rasvaisuusluokkaan 3 luokittuvat eläimet painoivat aineistossa keskimäärin 215 (ab) ja 212 (hf) kg. Vastaavat teuraspainot olivat si- ja li-rodun hiehoilla 245 (si) ja 253 (li) kg. Rasvaisuusluokkaan 3 luokittuvilla ch- ja ba-hiehoilla keskimääräinen teuraspaino oli selkeästi muita rotuja korkeampi (ch $262 \mathrm{~kg}$ ja ba $271 \mathrm{~kg}$ ).

Taulukko 4. Liharotuisten hiehojen keskimääräinen teuraspaino eri rasvaisuusluokissa $(\mathrm{AB}=$ aberdeen angus, $\mathrm{BA}=$ blonde d'Aquitaine, $\mathrm{CH}=$ charolais, $\mathrm{HF}=$ hereford, $\mathrm{LI}=$ limousin, $\mathrm{SI}=$ simmental).

\begin{tabular}{|c|c|c|c|c|c|c|c|c|c|}
\hline $\begin{array}{l}\text { Rasvaisuus- } \\
\text { luokka }\end{array}$ & $\begin{array}{c}\text { Havaintojen } \\
\text { lukumäärä }\end{array}$ & $\mathrm{AB}$ & BA & $\mathrm{CH}$ & $\mathrm{HF}$ & LI & SI & SEM $^{1}$ & $\begin{array}{l}\text { Tilastollinen } \\
\text { merkitsevyys }\end{array}$ \\
\hline 1 & 219 & $97^{\mathrm{a}}$ & $231^{b}$ & $184^{\mathrm{cd}}$ & $141^{\mathrm{e}}$ & $192^{\mathrm{c}}$ & $165^{\mathrm{de}}$ & 9,6 & $* * *$ \\
\hline 2 & 1554 & $178^{\mathrm{a}}$ & $246^{\mathrm{b}}$ & $230^{c}$ & $180^{\mathrm{a}}$ & $236^{\mathrm{d}}$ & $220^{\mathrm{e}}$ & 3,9 & $* * *$ \\
\hline 3 & 2969 & $215^{\mathrm{a}}$ & $271^{\mathrm{b}}$ & $262^{\mathrm{b}}$ & $212^{\mathrm{a}}$ & $253^{\mathrm{c}}$ & $245^{\mathrm{d}}$ & 4,6 & $* * *$ \\
\hline 4 & 2729 & $237^{\mathrm{a}}$ & $267^{b c}$ & $279^{\mathrm{b}}$ & $235^{\mathrm{b}}$ & $267^{\mathrm{c}}$ & $268^{c}$ & 6,2 & $* * *$ \\
\hline 5 & 1272 & $259^{\mathrm{a}}$ & $294^{\mathrm{abc}}$ & $303^{b}$ & $259^{\mathrm{a}}$ & $280^{\mathrm{c}}$ & $282^{c}$ & 20,9 & $* * *$ \\
\hline
\end{tabular}




\section{Teuraspainon vaikutus ruhon lihakkuuteen}

Ruhojen rasvaisuuden ja teuraspainon lisäksi lihakkuusluokka vaikuttaa merkittävästi eläimestä saatavaan tilityshintaan. Tavoitteena tulisikin olla, että liharotuiset sonnit luokittuisivat vähintään lihakkuusluokkaan R-. Taulukossa 5 on esitetty tämän aineiston sonnien keskimääräiset teuraspainot lihakkuusluokittain. Tarkasteltaessa lihakkuusluokkaa R- esille nousevat erityisesti ba- ja li-rotujen hyvät lihakkuusominaisuudet jo matalissa teuraspainoissa. Näiden rotujen sonnit luokittuivat kyseiseen lihakkuusluokkaan jo keskimäärin $350 \mathrm{~kg}: n$ teuraspainossa. Sen sijaan si-sonnit saavuttivat luokan Rvasta keskimäärin $381 \mathrm{~kg}: n$ painossa.

Mielenkiintoista on ab- ja hf-rotujen luokittuminen, sillä näillä roduilla lihakkuusluokka R- saavutettiin teuraspainoissa 376 (ab) ja $379 \mathrm{~kg}$ (hf). Aikaisemman rasvaisuustarkastelun perusteella voidaan puolestaan havaita, että luokkaan R- luokittuvilla ab- ja hf-sonneilla on siten selkeä riski luokittua rasvaisuuden osalta luokkiin 4-5. Näin ollen lihakkuusluokan R- saavuttaminen siten, että rasvaisuusluokka on enintään 3, on varsin haastavaa ab- ja hf-rodun sonneille. Viime kädessä optimaalisen teuraspainon ratkaiseekin se, painotetaanko ruhojen hinnoittelussa enemmän lihakkuutta vai rasvaisuutta.

Taulukko 5. Liharotuisten sonnien keskimääräinen teuraspaino eri lihakkuusluokissa ( $\mathrm{AB}=$ aberdeen angus, $\mathrm{B} A$ = blonde d'Aquitaine, $\mathrm{CH}=$ charolais, $\mathrm{HF}=$ hereford, $\mathrm{LI}=$ limousin, $\mathrm{SI}=$ simmental).

\begin{tabular}{|c|c|c|c|c|c|c|c|c|c|}
\hline $\begin{array}{l}\text { Lihakkuus- } \\
\text { luokka }\end{array}$ & $\begin{array}{c}\text { Havaintojen } \\
\text { lukumäärä }\end{array}$ & $\mathrm{AB}$ & $\mathrm{BA}$ & $\mathrm{CH}$ & $\mathrm{HF}$ & LI & SI & SEM $^{1}$ & $\begin{array}{l}\text { Tilastollinen } \\
\text { merkitsevyys }\end{array}$ \\
\hline P- & 3 & - & - & 122 & 151 & - & - & - & \\
\hline $\mathrm{P}$ & 30 & 147 & - & 204 & 148 & 124 & - & 39,8 & \\
\hline $\mathrm{P}+$ & 123 & 210 & 197 & 216 & 192 & 204 & 200 & 47,4 & \\
\hline O- & 447 & 283 & 336 & 261 & 268 & 266 & 271 & 58,9 & \\
\hline $\mathrm{O}$ & 1433 & $318^{\mathrm{a}}$ & $273^{b}$ & $294^{\mathrm{b}}$ & $315^{a}$ & $290^{\mathrm{b}}$ & $311^{\mathrm{a}}$ & 16,3 & $* * *$ \\
\hline $\mathrm{O}+$ & 2487 & $350^{\mathrm{a}}$ & $292^{c}$ & $325^{\mathrm{d}}$ & $345^{b}$ & $317^{\mathrm{e}}$ & $344^{\mathrm{ab}}$ & 10,8 & $* * *$ \\
\hline R- & 4985 & $376^{\mathrm{a}}$ & $350^{\mathrm{b}}$ & $369^{c}$ & $379^{d}$ & $352^{\mathrm{b}}$ & $381^{\mathrm{d}}$ & 6,9 & $* * *$ \\
\hline $\mathrm{R}$ & 4513 & $395^{\mathrm{a}}$ & $381^{\mathrm{b}}$ & $395^{\mathrm{a}}$ & $400^{c}$ & $371^{\mathrm{b}}$ & $402^{c}$ & 5,9 & $* * *$ \\
\hline $\mathrm{R}+$ & 2826 & $407^{\mathrm{a}}$ & $396^{\mathrm{ab}}$ & $417^{\mathrm{c}}$ & $421^{c}$ & $390^{\mathrm{b}}$ & $422^{c}$ & 6,5 & $* * *$ \\
\hline U- & 816 & $433^{\mathrm{a}}$ & $383^{\mathrm{b}}$ & $441^{\mathrm{a}}$ & $434^{\mathrm{a}}$ & $404^{b}$ & $442^{\mathrm{a}}$ & 14,1 & $* * *$ \\
\hline $\mathrm{U}$ & 2381 & $449^{\mathrm{ab}}$ & $404^{\mathrm{c}}$ & $447^{\mathrm{a}}$ & $442^{\mathrm{ab}}$ & $414^{\mathrm{c}}$ & $455^{\mathrm{b}}$ & 6,0 & $* * *$ \\
\hline U+ & 386 & $443^{\mathrm{ab}}$ & $407^{\mathrm{bc}}$ & $458^{\mathrm{a}}$ & $447^{\mathrm{a}}$ & $419^{c}$ & $467^{\mathrm{a}}$ & 19,4 & $* * *$ \\
\hline E- & 272 & $430^{\mathrm{abcd}}$ & $419^{a}$ & $470^{\mathrm{b}}$ & $495^{\mathrm{abcd}}$ & $434^{\mathrm{ac}}$ & $487^{\text {bd }}$ & 43,8 & $* * *$ \\
\hline $\mathrm{E}$ & 839 & $447^{\mathrm{abcd}}$ & $432^{\mathrm{a}}$ & $475^{\mathrm{b}}$ & $502^{\mathrm{abcd}}$ & $442^{\mathrm{ac}}$ & $494^{\mathrm{d}}$ & 46,3 & $* * *$ \\
\hline $\mathrm{E}+$ & 69 & - & $476^{\mathrm{a}}$ & $500^{\mathrm{b}}$ & $336^{\mathrm{c}}$ & $456^{\mathrm{a}}$ & - & 32,2 & $* * *$ \\
\hline
\end{tabular}

${ }^{1} \mathrm{SEM}=$ Keskiarvon keskivirhe

${ }^{2}$ Tilastollisesti merkitsevästi $(\mathrm{p}<0,05)$ toisistaan eroavat keskiarvot on merkitty taulukkoon eri yläindekseillä. $* * *(\mathrm{p}<0,001), * *(\mathrm{p}<0,01), *(\mathrm{p}<0,05)$ ja o $(\mathrm{p}<0,10)$.

Hiehojen osalta kaikkein korkeimpiin lihakkuusluokkiin (U+, E-, E, E+) luokittui vain yksittäisiä eläimiä. Lihakkuusluokkiin R+, U- ja U luokittui lähinnä vain li-, ch- ja ba-rodun hiehoja sekä seitsemän si- ja hf-rodun hiehoa ja kolme ab-rodun hiehoa. Suurin osa hiehoista luokittui luokkien O- ja R välille. Ba-rodun osalta hiehoaineisto ei antane luotettavaa kuvaa rodun lihakkuusominaisuuksista eri teuraspainoissa, sillä koko aineisto sisälsi ainoastaan 147 ba-rodun hiehoa, jolloin yksittäisten lihakkuusluokkien sisältämät havaintomäärät jäivät varsin pieniksi. Limousinin osalta hyvät lihakkuusominaisuudet nousivat esille myös hiehoaineistossa, sillä esimerkiksi O+ lihakkuusluokkaan luokittuneet li-hiehot saavuttivat luokan merkitsevästi kaikkia muita rotuja alemmassa teuraspainossa (Taulukko $6)$.

Liharodut voidaan Phillipsin (2010) mukaan jakaa kasvurytmin mukaan kolmeen eri luokkaan: 1. aikainen (angus), 2. keski (hereford) ja 3. myöhäinen (charolais, blonde d'aquitaine, limousin, simmental). Kasvurytmiin vaikuttavat eläimen aikuiskoko ja kudosjakauma (lihas- ja rasvakudoksen suhde) (Field 2007). Kasvurytmin avulla voidaan arvioida lihantuotantoeläimen taloudellinen kasvatusaika. Kasvurytmi määrittää, milloin eläin saavuttaa suku- ja teuraskypsyyden. Sukukypsyyden jälkeen kehoon kerääntyvä rasvanmäärä lisääntyy. Suomalaisen teurasaineiston tulokset näyttävät olevan hyvin samansuuntaisia, mitä rotujen välisistä eroista on esitetty ulkomaisessa kirjallisuudessa (esim. Olesen ym. 2004, Field 2007, Dubouet 2010, Phillips 2010). Esimerkiksi ranskalaisessa teuraskasvatuk- 
sessa limousin-rodun ehdottomana valttina pidetään teurasominaisuuksien laaja-alaisuutta. Jo nuoret eläimet (ikä 9 kuukautta) ovat ns. teuraskypsiä, toisaalta hiehoja voidaan kasvattaa 36 kuukauden teurasikään teurasominaisuuksien kärsimättä (Dubouet 2010). Simmental-rodun on puolestaan todettu olevan suhteellisen myöhäinen teuraskasvatuksessa ja hyvä päiväkasvu vaatii rehuilta suurta energiatiheyttä (Field 2007, Phillips 2010). Teurasruhoissa simmentalilla voidaan tavoitella suuriakin painoja (Phillips 2010), mutta rasvoittuminen voi kuitenkin asettaa rajoituksensa, koska simmental-eläimet rasvoittuvat herkemmin kuin ranskalaiset rodut (Field 2007).

Eri rotujen erilaiset kasvurytmit ja lihakkuusominaisuudet tulisi ottaa huomioon valittavassa kasvatus- ja rehustusstrategiassa. Keskikokoiset ab- ja hf-rodut sopivat paremmin karkearehuvaltaiseen ja vähemmän intensiiviseen kasvatusmalliin (Dufey ym. 2002, Phillips 2010). Isot rodut puolestaan hyötyvät intensiivisestä, väkirehuvaltaisesta kasvatuksesta (Dufey ym. 2002, Phillips 2010). Lihaksen kasvukyky on isoilla roduilla hyvä ja luokittuminen hyviin lihakkuusluokkiin tapahtuu jo matalissakin teuraspainoissa (Phillips 2010). Erilaisilla kasvatusmalleilla pystytään hyödyntämään rotutyypillisiä ominaisuuksia parhaan mahdollisen lopputuloksen saavuttamiseksi sekä yksittäisen tilan että markkinoiden kannalta.

Taulukko 6. Liharotuisten hiehojen keskimääräinen teuraspaino eri lihakkuusluokissa ( $\mathrm{AB}=$ aberdeen angus, $\mathrm{BA}$ = blonde d'Aquitaine, $\mathrm{CH}=$ charolais, $\mathrm{HF}=$ hereford, $\mathrm{LI}=$ limousin, $\mathrm{SI}=$ simmental).

\begin{tabular}{llllllllll}
$\begin{array}{l}\text { Lihakkuus- } \\
\text { luokka }\end{array}$ & $\begin{array}{l}\text { Havaintojen } \\
\text { lukumäärä }\end{array}$ & $\mathrm{AB}$ & $\mathrm{BA}$ & $\mathrm{CH}$ & $\mathrm{HF}$ & $\mathrm{LI}$ & SI & SEM & $\begin{array}{c}\text { Tilastollinen } \\
\text { merkitsevyys }\end{array}$ \\
\hline $\mathrm{P}-$ & 7 & 86 & - & 117 & 116 & - & - & 12,5 & \\
$\mathrm{P}$ & 66 & $122^{\mathrm{a}}$ & - & $138^{\mathrm{ab}}$ & $167^{\mathrm{c}}$ & $118^{\mathrm{abc}}$ & $165^{\mathrm{bc}}$ & 33,6 & $* * *$ \\
$\mathrm{P}+$ & 286 & $186^{\mathrm{ac}}$ & $143^{\mathrm{ab}}$ & $169^{\mathrm{b}}$ & $188^{\mathrm{ac}}$ & $203^{\mathrm{c}}$ & $174^{\mathrm{ab}}$ & 23,9 & $*$ \\
$\mathrm{O}-$ & 1098 & $218^{\mathrm{a}}$ & $199^{\mathrm{abc}}$ & $210^{\mathrm{bc}}$ & $215^{\mathrm{ab}}$ & $206^{\mathrm{c}}$ & $230^{\mathrm{d}}$ & 13,4 & $* * *$ \\
$\mathrm{O}$ & 2130 & $231^{\mathrm{a}}$ & $217^{\mathrm{ab}}$ & $231^{\mathrm{ac}}$ & $231^{\mathrm{a}}$ & $225^{\mathrm{b}}$ & $237^{\mathrm{c}}$ & 9,1 & $* *$ \\
$\mathrm{O}+$ & 2118 & $244^{\mathrm{a}}$ & $251^{\mathrm{ab}}$ & $251^{\mathrm{b}}$ & $249^{\mathrm{b}}$ & $239^{\mathrm{c}}$ & $248^{\mathrm{ab}}$ & 5,6 & $* * *$ \\
$\mathrm{R}-$ & 1526 & $260^{\mathrm{a}}$ & $249^{\mathrm{ab}}$ & $267^{\mathrm{c}}$ & $256^{\mathrm{a}}$ & $250^{\mathrm{b}}$ & $260^{\mathrm{a}}$ & 5,6 & $* * *$ \\
$\mathrm{R}$ & 982 & $267^{\mathrm{ab}}$ & $255^{\mathrm{a}}$ & $280^{\mathrm{b}}$ & $268^{\mathrm{ac}}$ & $260^{\mathrm{a}}$ & $272^{\mathrm{bc}}$ & 5,7 & $* * *$ \\
$\mathrm{R}+$ & 362 & $262^{\mathrm{abc}}$ & $265^{\mathrm{a}}$ & $294^{\mathrm{b}}$ & $284^{\mathrm{ab}}$ & $271^{\mathrm{a}}$ & $273^{\mathrm{ab}}$ & 18,0 & $* * *$ \\
$\mathrm{U}-$ & 41 & - & 338 & 292 & - & 283 & 298 & 29,8 & \\
$\mathrm{U}$ & 92 & - & $286^{\mathrm{ab}}$ & $292^{\mathrm{a}}$ & $366^{\mathrm{c}}$ & $275^{\mathrm{b}}$ & - & 34,8 & $*$ \\
$\mathrm{U}+$ & 10 & - & 263 & 288 & - & 283 & - & 25,4 & \\
E- & 10 & - & 289 & 310 & - & 270 & - & 25,6 & \\
$\mathrm{E}$ & 12 & - & 254 & 280 & - & 275 & - & 23,0 & \\
E+ & 1 & - & 327 & - & - & - & - & & \\
\hline
\end{tabular}

${ }^{1}$ SEM = Keskiarvon keskivirhe.

${ }^{2}$ Tilastollisesti merkitsevästi $(\mathrm{p}<0,05)$ toisistaan eroavat keskiarvot on merkitty taulukkoon eri yläindekseillä. $* * *(\mathrm{p}<0,001), * *(\mathrm{p}<0,01), *(\mathrm{p}<0,05)$ ja o $(\mathrm{p}<0,10)$.

\section{Yhteenveto ja johtopäätökset}

Liharotuisten nautojen välillä on selkeitä rotueroja tuotanto-ominaisuuksissa. Lähtökohtaisesti yksikään rotu ei kuitenkaan ole ylivertainen kaikissa ominaisuuksissa, joita tarvitaan emolehmätuotantoon perustuvassa naudanlihantuotannossa. Tässä tutkimuksessa tarkasteltiin kasvu- ja teurasominaisuuksia, jolloin ch-, li- ja ba-rotujen hyvät ominaisuudet nousivat selkeästi esille. Ch-, li- ja ba-rodut edustavatkin tyypillisimmillään ns. pääterotuja, joilla on jo jalostuksellisesti kiinnitetty erityisesti huomiota juuri erinomaiseen teurastulokseen. Keskikokoisten ab- ja hf-rotujen eli ns. emorotujen vahvuudet tulevat puolestaan selkeimmin esille, kun tarkastellaan emolehmien rehunkäyttökykyä ja toisaalta naudanlihan marmoroitumista ja syöntilaatua sekä naudanlihan rasvahappokoostumusta ihmisen terveyden kannalta.

Keskikokoisilla hf- ja ab-rodun sonneilla ruhojen rasvoittuminen alkaa lisääntyä huomattavasti, jos tavoitellaan yli $400 \mathrm{~kg}$ teuraspainoja. Pääterotujen sonnit pystytään puolestaan kasvattamaan selvästi yli $400 \mathrm{~kg}$ teuraspainoihin ilman rasvoittumista. Eri liharotujen kasvu- ja teurasominaisuudet ovat erilaisia. Onkin resurssien tuhlausta yrittää saavuttaa hyvä teurastulos samankaltaisella kasvatusstrategialla kaikilla roduilla ja rotuyhdistelmillä. 


\section{Kirjallisuus}

Dubouet, C. 2010. La production des bovines allaitants. 3e edition. Conduite. Qualité. Gestion. Guides France Agricole, Paris. 414 s.

Dufey, P.-A., Chambaz, A. Morel, I. \& Chassot, A. 2002. Performances d'engraissement de bœufs de six races à viande. Revue Suisse Agriculture 34: 117-124.

Field, T.G. 2007. Beef production and management decisions. 5th Edition. New Jersey: Pearson Prentice Hall, Upper Saddle River. 718 s.

Herva, T., Huuskonen, A., Virtala, A.-M. \& Peltoniemi, O. 2011. On-farm welfare and carcass fat score of bulls at slaughter. Livestock Science 138: 159-166.

Herva, T., Virtala, A-M., Huuskonen, A., Saatkamp, H. W. \& Peltoniemi, O. 2009. On-farm welfare and estimated daily carcass gain of slaughtered bulls. Acta Agric. Scand. Sect. A Anim. Sci. 59: 104-120.

Huuskonen, A., Jansson, S., Honkavaara, M., Tuomisto, L., Kauppinen, R. \& Joki-Tokola, E. 2010. Meat colour, fatty acid profile and carcass characteristics of Hereford bulls finished on grazed pasture or grass silagebased diets with similar concentrate allowance. Livest. Sci. 131: 125-129.

Huuskonen, A., Tuomisto, L., Joki-Tokola, E. \& Kauppinen, R. 2009. Animal performance and carcass characteristics of growing Hereford bulls under insulated, uninsulated and outdoor housing conditions in Northern Finland. Agric. Food Sci. 18: 16-26.

Manninen, M., Honkavaara, M., Jauhiainen, L., Nykänen, A. \& Heikkilä, A-M. 2011. Effects of grass-red clover silage digestibility and concentrate protein concentration on performance, carcass value, eating quality, and economy of finishing Hereford-bulls reared in cold conditions. Agric. Food Sci. 20: 151-168.

Manninen, M., Holma, M., Jauhiainen, L. \& Suvitie, M. 2004a. Väkirehun kasviöljyn ja E-vitamiinin vaikutus naudanlihan koostumukseen. Teoksessa: Toim. Anneli Hopponen ja Marketta Rinne. Maataloustieteen Päivät 2004. Suomen maataloustieteellisen seuran tiedote 19: $4 \mathrm{~s}$.

Manninen, M., Huhta, H., Virkajärvi, P., Joki-Tokola, E., Suvitie, M., Puntila, M.-L. \& Röpelinen, A. 1994. Risteytyseläinten ruokinta- ja kasvatuskokeet sekä ruhon ja lihan laatu. Teoksessa: toim. Tarja Korhonen ja Minna Toivonen. Naudanlihantuotannon kehittäminen: Naudanlihantuotannon edistämisprojektin loppuraportti. Helsinki: Maa- ja metsätalousministeriö. s. 35-80.

Manninen, M., Jauhiainen, L., Ruusunen, M., Soveri, T., Koho, N. \& Pösö, R. 2010. Effects of concentrate type and level on the performance and health of finishing Hereford bulls given a grass silage-based diet and reared in cold conditions. Livest. Sci. 127: 227-237.

Manninen, M., Nykänen, A., Jauhiainen, L. \& Suvitie, M. 2006a. Ohra-hernekokoviljasäilörehun ja loppukasvatuksen väkirehuintensiteetin vaikutus hereford-sonnien tuotantoon. Teoksessa: Toim. Leena RantamäkiLahtinen ja Kirsi Partanen. Maataloustieteen Päivät 2006. Suomen maataloustieteellisen seuran tiedote 22: s. 233.

Manninen, M., Nykänen, A., Musikka, T. \& Ojajärvi, P. 2006b. Herne ja rypsipuriste teuraaksi kasvatettavien hereford-hiehojen valkuaislähteenä vieroituksen jälkeisessä ruokinnassa. Teoksessa: Toim. Leena RantamäkiLahtinen ja Kirsi Partanen. Maataloustieteen Päivät 2006. Suomen maataloustieteellisen seuran tiedote 22: s. 232.

Manninen, M., Nykänen, A., Ojajärvi, P., Musikka, T. \& Suvitie, M. 2006. Luomukasvustosta valmistettu vehnä-rehuvirnasäilörehu teuraaksi kasvatettavien hereford-hiehojen vieroituksen jälkeisessä ruokinnassa. Teoksessa: Toim. Leena Rantamäki-Lahtinen ja Kirsi Partanen. Maataloustieteen Päivät 2006. Suomen maataloustieteellisen seuran tiedote 22: s. 165.

Manninen, M., Ojajärvi, P. \& Suvitie, M. 2004b. Kaura-rehuvirnasäilörehu teurashiehojen ruokinnassa. Teoksessa: Toim. Marketta Rinne. Maataloustieteen Päivät 2004. Suomen maataloustieteellisen seuran tiedote 20: s. 103.

Olesen, M., Madsen, P., Andersen, B.B., Madsen, N.T. \& Andersen, H.R. 2004. Feed intake and production of different biological types of beef breeds. DJF rapport Husdyrbrug nr. $59.65 \mathrm{~s}$.

Owens, F.N., Dubeski, P. \& Hanson, C.F. 1993. Factors that alter the growth and development of ruminants. J. Anim. Sci. 71: 3138-3150.

Phillips, C.J.C. 2010. Principles of cattle production. 2nd Edition. Cambridge: CABI Publications, Cambridge University Press. 233 s.

Steen, R.W.J. \& Kilpatrick, D. 1995. Effects of plane of nutrition and slaughter weight on the carcass composition of serially slaughtered bulls, steers and heifers of three breed crosses. Livest. Prod. Sci. 43: 205-213. 